\title{
Effect of Biochar Application on Growth of Garden Pea (Pisum sativum L.) in Acidic Soils of Bule Woreda Gedeo Zone Southern Ethiopia
}

\author{
Tariku Berihun, ${ }^{1}$ Shiferaw Tolosa, ${ }^{2}$ Muluken Tadele, ${ }^{1}$ and Firew Kebede ${ }^{3}$ \\ ${ }^{1}$ Department of Biology, Dilla University, P.O. Box 419, Dilla, Ethiopia \\ ${ }^{2}$ Department of Plant Science, Dilla University, P.O. Box 419, Dilla, Ethiopia \\ ${ }^{3}$ Department of Biology, Hawassa University, P.O. Box 05, Hawassa, Ethiopia
}

Correspondence should be addressed to Tariku Berihun; berihun.tariku@yahoo.com

Received 12 January 2017; Accepted 24 April 2017; Published 23 May 2017

Academic Editor: David Clay

Copyright (C) 2017 Tariku Berihun et al. This is an open access article distributed under the Creative Commons Attribution License, which permits unrestricted use, distribution, and reproduction in any medium, provided the original work is properly cited.

\begin{abstract}
The aim of this experiment was to study the effect of types and rates of biochar on growth, yield, and yield component of garden pea at Bule wereda, Southern Ethiopia. The treatments consist of two types of biochar (corncobs and Lantana camara) and four rates of biochar $\left(0,6,12\right.$, and $\left.18 \mathrm{tha}^{-1}\right)$. The experiment was laid out as a randomized complete block design in a factorial arrangement with three replications. Soil samples were collected at a depth of $0-30 \mathrm{~cm}$ and germination parameter and phonology of garden pea were recorded. The result showed that soil bulk density, porosity, $\mathrm{pH}$, and exchangeable acidity were significantly $(P<0.001)$ affected by biochar application. The result also showed that maximum germination percentage of garden pea seeds (95.23\%) was recorded at $18 \mathrm{t} \mathrm{ha}^{-1}$ of Lantana biochar. The shoot length was significantly $(P<0.05)$ affected at 15 days and 30 days of biochar application. Moreover, fresh shoot weight and dry root biomass, number of seeds per pod, and grain yield of garden pea were significantly affected $(P<0.05)$. Of the substrate and application rate applied, Lantana camara $12 \mathrm{tha}^{-1}$ and Lantana camara $18 \mathrm{tha}^{-1}$ significantly increased yield of garden pea. Thus, further studies on effect of different biochars and their specific role are suggested to increase crop production.
\end{abstract}

\section{Introduction}

1.1. Background of the Study. Soil acidity reduces $30-40 \%$ of world's arable land crop production [1]. There are several estimates of the extent of acid soils and its impacts on crop production in the world. According to [2] acidic soils cover 1,455 million ha or about $11 \%$ of the total global land surface. Other scholars such as [3] had higher estimates and reported that acid soils covered 3,950 million ha or $30 \%$ of global arable land.

In Ethiopia $40.9 \%$ of the soil is acidic; out of which $27.7 \%$ is moderately to weakly acidic ( $\mathrm{pH}$ of $5.5-6.7)$ and $13.2 \%$ is strongly to moderately acidic $(\mathrm{pH}<5.5)[4]$. A secondary data obtained from Gedeo zone agricultural office indicates that Bule wereda was soil strongly affected by soil acidity. The soil $\mathrm{pH}$ of the study area is less than 5.5. This indicates that Bule wereda soil $\mathrm{pH}$ is categorized under strongly acidic soils [5].
Low crop productivity in many regions of the world is mainly caused by low soil $\mathrm{pH}$ and high aluminum content [6]. The soil amendments widely used to increase soil $\mathrm{pH}$ include dolomite, calcite, and lime and which in turn reduce exchangeable aluminum, iron, and hydronium in the soil [79]. Application of lime not only increases the soil $\mathrm{pH}$, base saturation, exchangeable calcium, and magnesium but also increases crop yield $[1,10]$. However, limestone material is relatively expensive and challenging to afford for the subsistence farmers and the supply is limited supply in Ethiopia [11-13]. Due to this, farmers have recently started using biochar and organic matter as an alternative soil amendment mechanism and increase crop yield as these materials are locally available and cheaper compared to limestone [12, 14].

The use of biochar for soil improvement for crop yields in agricultural fields is lately recognized [15]. Biochar is carbon rich product obtained from different feedstock at low 


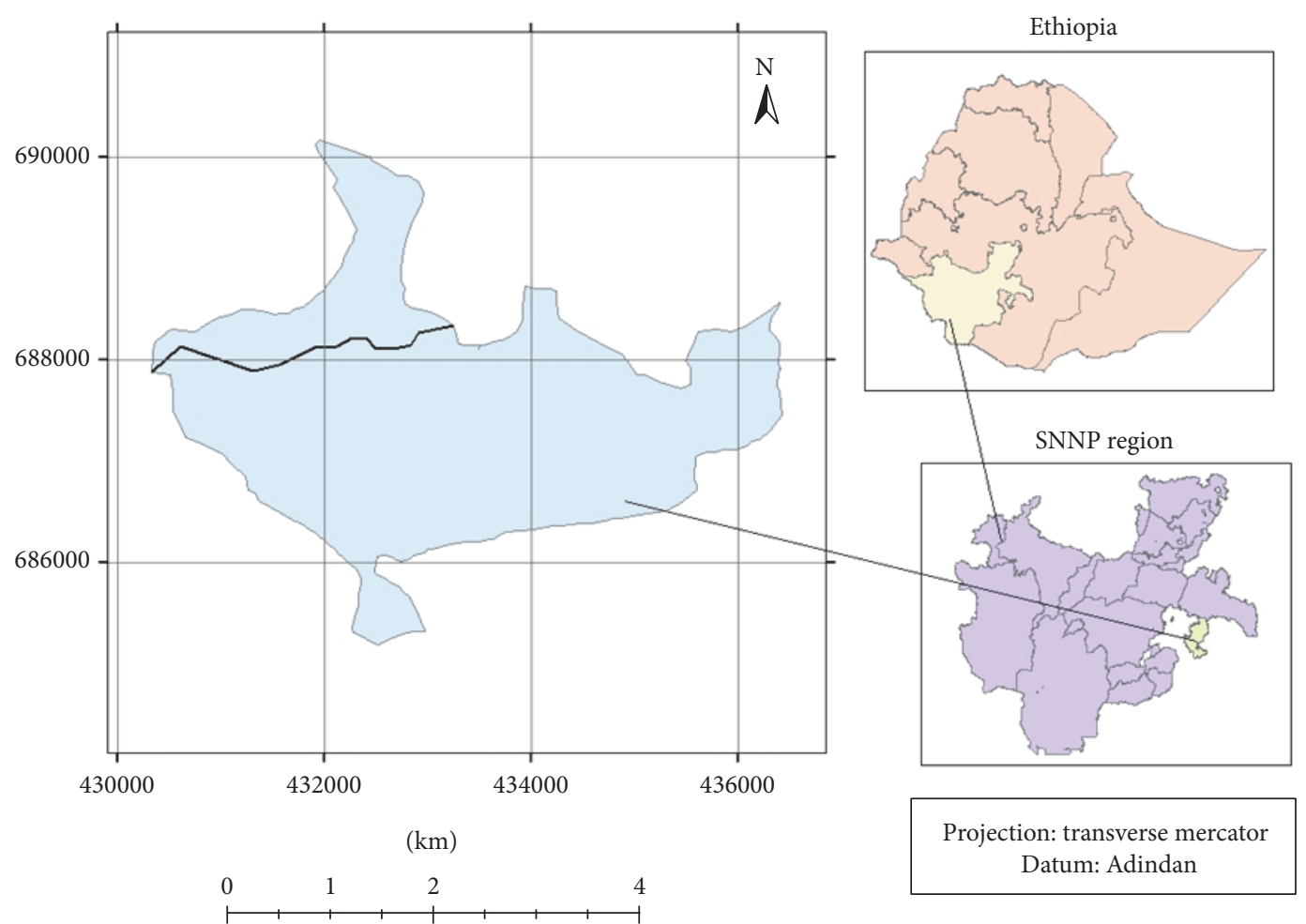

$\sim \operatorname{Road}$

Figure 1: Map of the study area.

temperatures $\left(<700^{\circ} \mathrm{C}\right)[16]$. It stores carbon for long time to improve soil fertility and optimized soil $\mathrm{pH}$ [17]. Application biochar not only increases crop productivity and soil cation exchange capacity (CEC) but also is possible to increase soil macro- and microelement [18-20]. Biochar is made from different feedstock such as wood chip and wood pellets, tree bark, crop residues, and organic wastes [14]. Different studies reported that biochar increases soil $\mathrm{pH}$, plant growth, and yield $[6,21]$ but few studies reported the influence of biochar on early stages of plant growth such as on seed germination and seedling growth in different regions of the world [8].

In Ethiopia most studies have focused on effect of biochar on soil physical and chemical properties and have not investigated the impact on seed germination or root growth $[6,22]$. Therefore this study was initiated (1) to evaluate the effects of Lantana camara and corncob biochar on yield and yield component of garden pea at Bule acidic soils and (2) to explore the effects of biochar on growth performance of garden pea.

\section{Materials and Methods}

2.1. Description of Study Area. The experiment was carried out at Bule woreda, Gedeo Zone, Southern Ethiopia (Figure 1). The area lies between $6^{\circ} 04^{\prime} 16^{\prime \prime}$ and $6^{\circ} 23^{\prime} 50^{\prime \prime} \mathrm{N}$ latitude and from $38^{\circ} 16^{\prime} 20^{\prime \prime}$ to $38^{\circ} 26^{\prime} 11^{\prime \prime} \mathrm{E}$ longitude at an altitude ranging from 1700 to 3000 meter above sea level [23]. The mean annual rainfall ranges from $1200 \mathrm{~mm}$ to $1800 \mathrm{~mm}$.

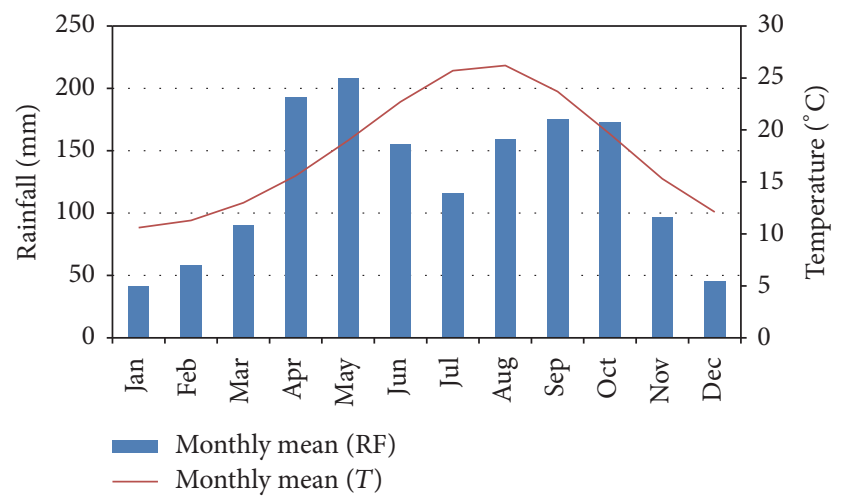

FIgURE 2: Mean monthly temperature $\left({ }^{\circ} \mathrm{C}\right)$ and rainfall in the study area (2003-2015). Source: Ethiopia Meteorological Agency, Hawassa Branch, 2016.

The area is characterized by a bimodal rainfall distribution (Figure 2). The mean annual temperature is $10.6^{\circ} \mathrm{C}$ and lies in the cold thermal zone of Ethiopia [24] indicating that only cold growing crops can be cultivated in the area. The area is also categorized as moist dega zone as per traditional system.

The soils of the experimental site are mainly nitisol [25]. The land-use system of the study area is a mixture of crop farming and agroforestry system [24]. Thus, $85 \%$ (21, $890 \mathrm{ha})$ of the land is used for growing annual and perennial crops while 497 ha are used for grazing, 1,904 ha 
TABLE 1: Treatment used in experimentation.

\begin{tabular}{lc}
\hline Treatment number & Amendment/plot \\
\hline 1 & $0 \mathrm{tha}^{-1}+$ corncob biochar $+2 \mathrm{~kg} \mathrm{NPS}$ \\
2 & $6 \mathrm{tha}^{-1}$ corncob biochar $+2 \mathrm{~kg} \mathrm{NPS}$ \\
3 & $12 \mathrm{tha}^{-1}$ corncob biochar $+2 \mathrm{~kg} \mathrm{NPS}$ \\
4 & $18 \mathrm{tha}^{-1}$ corncob biochar $+2 \mathrm{~kg} \mathrm{NPS}$ \\
5 & $0 \mathrm{tha}^{-1}+$ Lantana camara biochar $+2 \mathrm{~kg} \mathrm{NPS}$ \\
6 & $6 \mathrm{tha}^{-1}$ Lantana camara biochar $+2 \mathrm{~kg}$ NPS \\
7 & $12 \mathrm{t} \mathrm{ha}^{-1}$ Lantanacamara biochar $+2 \mathrm{~kg}$ NPS \\
8 & $18 \mathrm{tha}^{-1}$ Lantanacamara biochar $+2 \mathrm{~kg}$ NPS \\
\hline NPS stands for the fertilizers of nitrogen, phosphorus, and sulphur.
\end{tabular}

are covered by vegetation (mainly shrub land), 2,496 ha are used for settlement and other infrastructures, and 513 ha are categorized as nonusable. The dominant cereal crops growing in the area are Hordeum vulgare and Triticum aestivum, and tree species like Arundinaria alpine, Juniperus procera, Hagenia abyssinica (Kousso), Aningeria altissima (Kerero), and Eucalyptus globulus are the dominant species growing in the area. In addition to the cereal-based land-use system, agroforestry practices such as Ensete ventricosum (Kocho) were also used commonly by the local people.

2.2. Experimental Material. Tegegnech variety garden pea (Pisum sativum L.) was used for the study. Biochar from different feedstock (corncob and Lantana camara) is prepared using traditional earth mound technology [15]. After pyrolysis process, the biochar was grounded to small granules and passed through $2 \mathrm{~mm}$ sieve in order to have the same particle size as that of soil.

2.3. Experimental Treatments and Design. The experiments consist of two types of biochar (corncob and Lantana camara) and four rates $\left(0,6,12\right.$, and $\left.18 \mathrm{tha}^{-1}\right)$. The experiment was laid out as a randomized complete block design in a factorial arrangement with three replications. A total of 24 plots each measuring $2 \mathrm{~m} \times 2 \mathrm{~m}\left(4 \mathrm{~m}^{2}\right)$ were used for the experiment. Plots were separated by $0.5 \mathrm{~m}$ and each replicate was by $1 \mathrm{~m}$ apart to avoid edge effect. The description of treatment is shown in Table 1.

2.4. Experimental Procedures. Treatments were incorporated into the plots manually and left for 60 days. Priming of seed 24 hours before sowing was done to regulate the germination process. Plant to plant spacing is maintained $5 \mathrm{~cm}$ and row to row spacing is maintained $20 \mathrm{~cm}$ and planting depth was $1 \mathrm{~cm}$. There were 9 rows in each plot and 14 plants in each row and a total of 126 plants per plot. Weeding was done manually at two weeks interval till harvest. The recommended fertilizer $2 \mathrm{~kg}$ NPS (each $0.6 \mathrm{~kg}$ ) were applied during planting and the tested crop was raised under rain feed system.

2.5. Soil Sampling. Initial soil samples were collected randomly from twenty-four observational points on the site at the depth of $0-30 \mathrm{~cm}$ before the experiment. The soil samples were thoroughly mixed to form a composite soil sample and used for the determination of the soil physical and chemical properties. Also, core soil sampler of $167 \mathrm{~cm}^{3}$ was collected from 36 plots at the depth of $6 \mathrm{~cm}$ in each plot at 90 days and used for the determination of soil bulk density.

2.6. Soil Laboratory Analysis. Soil texture was determined by the hydrometer method. Bulk density was determined using the core method [26] in which a stainless steel core $(5 \mathrm{~cm}$ in diameter and $10 \mathrm{~cm}$ in height) was used to collect soil core to determine soil bulk density (Bd) in each sampling time during incubation. Total porosity ( $\mathrm{Tp}$ ) is calculated from bulk density using the formula $\mathrm{Tp}=100(1-\mathrm{Bd} / \mathrm{Pd})$, where $\mathrm{Bd}$ is bulk density, $\mathrm{Pd}$ is particles density, and $\mathrm{Pd}$ is assumed to be $2.65 \mathrm{~g} \mathrm{~cm}^{-3}$ [27]. Soil organic carbon was determined by the Walkley-Black oxidation method [28]. Total nitrogen was measured by the Kjeldahl method [27] and soil $\mathrm{pH}$ $\left(\mathrm{H}_{2} \mathrm{O}\right)$ by a $\mathrm{pH}$ meter with soil to water ratio of $1: 2.5$ [29]. Exchangeable acidity $\left(\mathrm{Al}^{+3}\right.$ and $\left.\mathrm{H}^{+}\right)$was titrated using $0.01 \mathrm{M}$ $\mathrm{NaOH}$ by extracting $4.0 \mathrm{~g}$ soil with $50 \mathrm{ml}$ of $1.0 \mathrm{M} \mathrm{KCl} \mathrm{[30].}$ Available phosphorus was determined by Bray-1 method, while potassium was measured with the flame photometry method [31].

\subsection{Agronomic Data Collection}

\subsubsection{Germination Parameter Study}

Germination. Germination percentage of seed from each treatment was calculated on the basis hypocotyls appeared above the surface of soil.

$$
\begin{aligned}
\text { Percentage of seed germination }(\%) & =\frac{x}{n} * 100, \\
\text { Mean germination time }(\mathrm{MGT}) & =\sum \frac{n i * t i}{n},
\end{aligned}
$$

where $n i$ is percentage of seeds germinated between two consecutive counts, $t i$ is time taken since germination experiment started, and $n$ is total percent of seeds germinated.

Germination Index. The numbers of germinated seeds were counted daily until the completion of experiment. Germination index (GI) was calculated using the following formula recommended by Khandakar and Bradbear (1983):

$$
\mathrm{GI}=\left(\frac{N_{1}}{1}+\frac{N_{2}}{2}+\frac{N_{3}}{3}+\frac{N_{4}}{4}+\cdots+\frac{N_{n}}{n}\right) \times 100,
$$

where $N_{1}, N_{2}, N_{3}, \ldots, N_{n}$, are proportions of seed which germinate on days $1,2,3, \ldots, n$ following setup of the experiment. If seeds sown were germinated at the same time equally, we considered all are germinated $100 \%$ while if none of the seeds are germinated all in all we considered the germination index is $0 \%$.

2.8. Phonological Observation of Garden Pea. Ten sample plants from each plot were selected randomly to determine various phenological characters such as shoot length and 
TABLE 2: Effect of biochar application on the soil bulk density, porosity, pH, SOC (\%), TN (\%), av. phosphorus, K, and exc. acidity.

\begin{tabular}{|c|c|c|c|c|c|c|c|c|}
\hline \multicolumn{9}{|c|}{ Soil physical properties } \\
\hline Rate of biochar $\mathrm{tha}^{-1}$ & $\mathrm{BD}\left(\mathrm{g} / \mathrm{cm}^{3}\right)$ & Porosity (\%) & $\mathrm{pH}$ & SOC (\%) & $\mathrm{TN}(\%)$ & $\begin{array}{l}\text { Av. phosphorus } \\
(\mathrm{PPm})\end{array}$ & $\mathrm{K}\left(\mathrm{Cmol}(+) \mathrm{kg}^{-1}\right)$ & $\begin{array}{l}\text { Exc. acidity } \\
(\mathrm{Cmol} / \mathrm{Kg})\end{array}$ \\
\hline \multicolumn{9}{|l|}{ Control } \\
\hline 0 & $0.91 \pm 0.01^{b}$ & $0.67 \pm 0.01^{\mathrm{a}}$ & $4.77 \pm 0.01^{\mathrm{a}}$ & $3.35 \pm 0.23^{\mathrm{a}}$ & $0.71 \pm 0.01^{\mathrm{a}}$ & $10.77 \pm 0.98^{\mathrm{a}}$ & $32.7 \pm 1.83^{\mathrm{a}}$ & $5.43 \pm 0.14^{\mathrm{b}}$ \\
\hline Corncob biochar & & & $5.27 \pm 0.10^{\mathrm{b}}$ & $4.86 \pm 0.06^{\mathrm{b}}$ & $0.77 \pm 0.01^{\mathrm{ab}}$ & $13.57 \pm 0.94^{\mathrm{b}}$ & $34.30 \pm 0.52^{\mathrm{ab}}$ & $4.85 \pm 0.71^{\mathrm{b}}$ \\
\hline $6 \mathrm{tha}^{-1}$ & $0.77 \pm 0.01^{\mathrm{a}}$ & $0.71 \pm 0.00^{\mathrm{b}}$ & $5.36 \pm 0.01^{\mathrm{c}}$ & $4.03 \pm 0.16^{\mathrm{b}}$ & $0.84 \pm 0.02^{\mathrm{bc}}$ & $13.40 \pm 1.50^{\mathrm{c}}$ & $37.51 \pm 1.21^{\mathrm{c}}$ & $5.04 \pm 0.60^{\mathrm{b}}$ \\
\hline $12 \mathrm{tha}^{-1}$ & $0.75 \pm 0.02^{\mathrm{a}}$ & $0.72 \pm 0.01^{\mathrm{b}}$ & $5.43 \pm 0.15^{\mathrm{c}}$ & $5.05 \pm 0.27^{\mathrm{b}}$ & $0.88 \pm 0.01^{\mathrm{c}}$ & $15.40 \pm 1.55^{\mathrm{c}}$ & $38.16 \pm 0.79^{c}$ & $3.70 \pm 0.87^{\mathrm{a}}$ \\
\hline $18 \mathrm{tha}^{-1}$ & $0.71 \pm 0.01^{\mathrm{a}}$ & $0.72 \pm 0.00^{\mathrm{b}}$ & $4.94 \pm 0.01^{\mathrm{a}}$ & $3.35 \pm 0.11^{\mathrm{a}}$ & $0.75 \pm 0.04^{\mathrm{a}}$ & $10.93 \pm 0.03^{\mathrm{a}}$ & $32.7 \pm 1.50^{\mathrm{a}}$ & $5.04 \pm 0.41^{\mathrm{b}}$ \\
\hline Lantana biochar & & & $5.55 \pm 0.02^{\mathrm{b}}$ & $4.45 \pm 0.42^{\mathrm{b}}$ & $0.76 \pm 0.01^{\mathrm{ab}}$ & $11.53 \pm 0.17^{\mathrm{b}}$ & $38.19 \pm 3.25^{\mathrm{ab}}$ & $3.89 \pm 1.20^{\mathrm{b}}$ \\
\hline $6 \mathrm{tha}^{-1}$ & $0.80 \pm 0.04^{\mathrm{a}}$ & $0.70 \pm 0.01^{\mathrm{b}}$ & $6.32 \pm 0.12^{c}$ & $4.53 \pm 0.44^{\mathrm{b}}$ & $0.82 \pm 0.05^{b c}$ & $13.77 \pm 0.81^{\mathrm{c}}$ & $40.37 \pm 1.20^{\mathrm{c}}$ & $2.24 \pm 0.61^{\mathrm{b}}$ \\
\hline $12 \mathrm{tha}^{-1}$ & $0.76 \pm 0.01^{\mathrm{a}}$ & $0.71 \pm 0.01^{\mathrm{b}}$ & $5.07 \pm 0.15^{\mathrm{c}}$ & $4.89 \pm 0.42^{\mathrm{b}}$ & $0.85 \pm 0.01^{\mathrm{c}}$ & $16.37 \pm 0.52^{\mathrm{c}}$ & $43.33 \pm 1.84^{\mathrm{c}}$ & $2.02 \pm 0.58^{\mathrm{a}}$ \\
\hline $18 \mathrm{tha}^{-1}$ & $0.72 \pm 0.02^{\mathrm{a}}$ & $0.74 \pm 0.00^{\mathrm{b}}$ & $4.77 \pm 0.01^{\mathrm{a}}$ & $3.35 \pm 0.23^{\mathrm{a}}$ & $0.71 \pm 0.01^{\mathrm{a}}$ & $10.77 \pm 0.98^{\mathrm{a}}$ & $32.7 \pm 1.83^{\mathrm{a}}$ & $5.43 \pm 0.14^{\mathrm{b}}$ \\
\hline $\operatorname{LSD}(P<0.05)$ & $<0.001$ & $<0.001$ & $<0.001$ & 4.86 & 0.77 & 13.57 & 34.30 & $<0.001$ \\
\hline CV (\%) & 11.3 & 13.5 & 18.12 & 16.14 & 12.05 & 19.33 & 17.07 & 15.12 \\
\hline
\end{tabular}

Means followed by the same letter(s) across columns and row are not significantly different $(P=0.05)$ with respect to substrate and application rate.

root length. The shoot and root length were measured in fresh using a ruler from the point near to soil surface to the longest portion of the plant tip at maturity and then average was calculated [32]. The parameters such as number of pods/plants, number of seeds/pods, fresh weight of shoot and roots, and dry biomass of shoot and root and the grain yields (kg/ha) were assessed [32].

2.9. Data Analysis. The data collected were subjected to descriptive statistics to calculate germination percentage, mean germination time, and germination index by using Ms-Excel spreadsheet version 2010. SAS version 9.1.3 was employed to determine analysis of variance (ANOVA) different phonological data of garden pea and the mean values were compared with least significant difference (LSD) at $P$ value 0.05 .

\section{Results and Discussions}

3.1. Soils of Experimental Site. Soil analysis before planting indicated that the soil had a medium $\mathrm{N}$ level $(0.5 \%)$, low soil organic C (3.1\%), medium available P level (12.4 ppm), low available $\mathrm{K}$ level $(38.4 \mathrm{ppm})$, and high exchangeable acidity $(4.32 \mathrm{Cmol} / \mathrm{kg})$ as per the criteria developed by [33] for Ethiopian soils and tropical soils. The $\mathrm{pH}$ of the soil was 4.7 showing very strongly acidic nature of the soil [24], bulk density $\left(0.82 \mathrm{~g} / \mathrm{cm}^{3}\right)$, particle size (51\%), sand (36\%), silt $(13 \%)$, and clay and textural class is sandy loam. The textural class of the experimental site was sandy loam.

3.2. Effect of Biochar on Soil Physical and Chemical Properties. Soil bulk density, porosity, $\mathrm{pH}$, and exchangeable acidity were significantly $(P<0.001)$ affected after the application of biochar Table 2. This is due to the presence of ash in the biochar that decreases in bulk density and exchangeable acidity and increases soil $\mathrm{pH}$ and soil porosity of the biochar amended soil [34]. These findings are in agreement with the recent research work by [11] who reported a decrease in

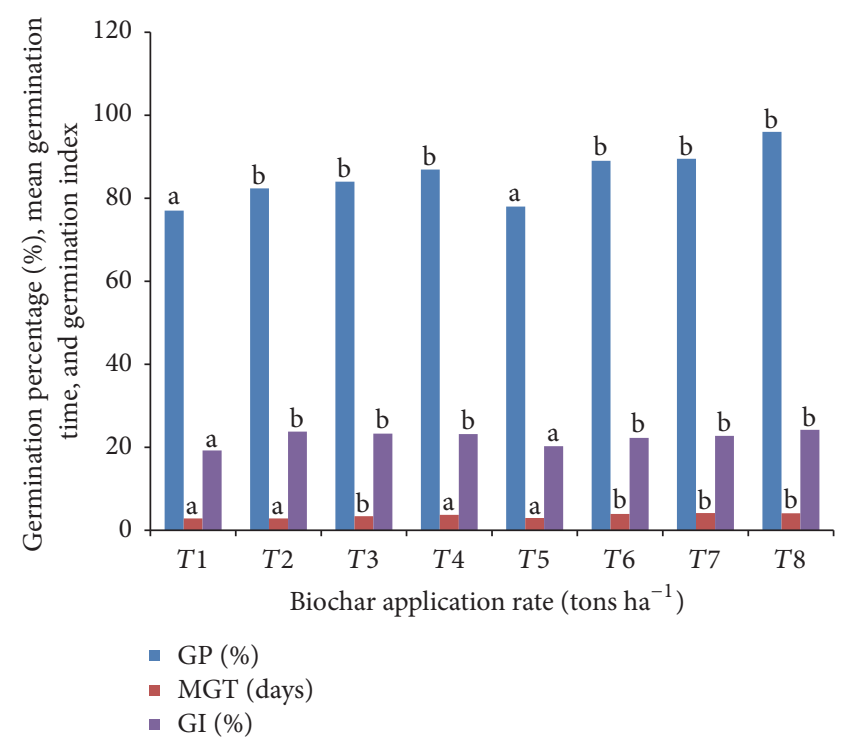

FIGURE 3: Effect of biochar on garden pea germination parameter.

soil bulk density and exchangeable acidity and increases in soil porosity and soil $\mathrm{pH}$ after biochar application, whereas total nitrogen, soil organic carbon, available phosphorus, and potassium are not significantly affected after application of (Table 2). This is attributed to the large carbon, nitrogen, and potassium component of inside the biochar [35]. Similarly [36] reported that significant increase of soil potassium, carbon and nitrogen, potassium, and available phosphorus was recorded by the application of biochar.

\subsection{Crop Phenology}

3.3.1. Effect of Biochars on Germination of Garden Pea Seed. The germination percentages (GP) range from 77 to $96.02 \%$ in different treatments but the statistical analysis revealed that it is not statistically significant differences (Figure 3). 
TABLE 3: Mean fifteen days, twenty days, twenty-five days, and thirty days of pea as influenced by different rate of biochar at Bule.

\begin{tabular}{|c|c|c|c|c|}
\hline Treatments & 15 days & 20 days & 25 days & 30 days \\
\hline \multicolumn{5}{|c|}{ Different rate of biochar $(\mathrm{kg} / \mathrm{ha})$} \\
\hline Control corn & $8.62^{\mathrm{ab}}$ & 10.83 & 16.01 & $29.33^{\mathrm{ab}}$ \\
\hline corn biochar $6 \mathrm{tha}^{-1}$ & $7.36^{\mathrm{c}}$ & 9.51 & 15.87 & $26.93^{\mathrm{b}}$ \\
\hline corn biochar $12 \mathrm{tha}^{-1}$ & $9.43^{\mathrm{ab}}$ & 11.41 & 18.70 & $30.93^{\mathrm{ab}}$ \\
\hline corn biochar $18 \mathrm{tha}^{-1}$ & $9.41^{\mathrm{ab}}$ & 10.65 & 16.19 & $26.47^{\mathrm{b}}$ \\
\hline Control Lantana & $8.97^{\mathrm{ab}}$ & 11.33 & 18.23 & $28.60^{\mathrm{ab}}$ \\
\hline Lantana biochar $6 \mathrm{tha}^{-1}$ & $9.03^{\mathrm{ab}}$ & 10.62 & 17.49 & $35.33^{\mathrm{a}}$ \\
\hline Lantana biochar $12 \mathrm{t} \mathrm{ha}^{-1}$ & $9.79^{\mathrm{a}}$ & 11.04 & 19.26 & $33.20^{\mathrm{ab}}$ \\
\hline Lantana biochar $18 \mathrm{tha}^{-1}$ & $8.57^{\mathrm{b}}$ & 10.93 & 16.83 & $29.800^{\mathrm{ab}}$ \\
\hline $\operatorname{LSD}(P<0.05)$ & 0.87 & NS & NS & 8.02 \\
\hline CV (\%) & 5.59 & 11.34 & 13.94 & 15.22 \\
\hline
\end{tabular}

NS = nonsignificant. Means with same letters are not significantly different from each other at 5\% probability level.

Similarly, other parameters such as mean germination time (MGT) and germination index (GI) were also affected by different rate of biochar as compared to the control. Biochar application did not decrease germination. The maximum germination percentage (GP), mean germination time (MGT), and germination index (GI) were $(96.02 \%$ and $24.03 \%)$ at rate of $18 \mathrm{tha}^{-1}$ of Lantana biochar application, respectively. This is due to the fact that biochar had a certain degree of adsorption and contains a certain amounts of minerals elements of soils which may provide nutrients for seed germination. Similarly [32] reported that biochar sorptive capacity for allelochemicals may increase in plant germination. This study was in agreement with [37] who reported that biochar application has been increase germination parameter of pea seeds.

3.4. Plant Height. Plant heights were influenced by biochar 15 and 30 days after planting. However, these differences disappeared by 15 days (Table 3 ). This could be due to the slow release of nutrients/to neutralize the acidic soil. The application of $12 \mathrm{tha}^{-1}$ of Lantana camara biochar significantly increased plant height as compared to other treatments in contrast to [36] where it was reported that biochar did not influence plant height.

3.5. Root Biomass. Both fresh and dry root biomasses were significantly affected by application of different rate of biochars $(P<0.005)$. Application of Lantana biochar at $6 \mathrm{tha}^{-1}$ and $18 \mathrm{tha}^{-1}$ significantly increased $(4.9$ and $4.7 \mathrm{~kg}$, resp.) fresh root biomass whereas application of Lantana biochar $6 \mathrm{tha}^{-1}$ increased $(3.10 \mathrm{~kg})$ the dry biomass as compared to other treatments (Table 4). One of the reasons for root biomass increased in this study was that the biochar of Lantana greatly improves the soil acidity and enhances root growth.

3.6. Pod Number per Plant. Pod number per plant was also significantly affected by different rate of biochar. The results indicated that the highest pod numbers $(28.67 \mathrm{~kg})$ were recorded under the application of Lantana biochar at the rate of $12 \mathrm{tha}^{-1}$ (Table 5). This might be due to the fact that
TABLE 4: Mean root length, root fresh weight, and root dry biomass of pea as influenced by different rate of biochar at Bule.

\begin{tabular}{lcc}
\hline Treatments & RFW $(\mathrm{kg})$ & RDB $(\mathrm{kg})$ \\
\hline Different rate of biochar $(\mathrm{kg} / \mathrm{ha})$ & & \\
\hline Control corn & $2.03^{\mathrm{c}}$ & $1.18^{\mathrm{d}}$ \\
corn biochar $6 \mathrm{t} \mathrm{ha}^{-1}$ & $1.56^{\mathrm{c}}$ & $1.35^{\mathrm{cd}}$ \\
corn biochar $12 \mathrm{t} \mathrm{ha}^{-1}$ & $3.50^{\mathrm{b}}$ & $1.99^{\mathrm{bc}}$ \\
corn biochar $18 \mathrm{t} \mathrm{ha}^{-1}$ & $3.33^{\mathrm{b}}$ & $2.36^{\mathrm{b}}$ \\
Control Lantana & $3.53^{\mathrm{b}}$ & $2.05^{\mathrm{bc}}$ \\
Lantana biochar 6 t ha & $-1.10^{\mathrm{a}}$ \\
Lantana biochar $12 \mathrm{t} \mathrm{ha}^{-1}$ & $4.93^{\mathrm{a}}$ & $2.37^{\mathrm{ab}}$ \\
Lantana biochar $18 \mathrm{tha}^{-1}$ & $4.00^{\mathrm{ab}}$ & $2.39^{\mathrm{ab}}$ \\
\hline LSD $(P<0.05)$ & $4.70^{\mathrm{a}}$ & 0.73 \\
\hline CV $(\%)$ & 1.05 & 19.97 \\
\hline
\end{tabular}

NS = nonsignificant, RL = root length, RFW = root fresh weight, and RDB $=$ root dry biomass. Means with same letters are not significantly different from each other at $5 \%$ probability level.

soil amelioration and crops supplied with adequate nutrients have more vegetative growth, longer linear growth rate, and more dry matter accumulation which is directly related to an increment in pod number. This result is in agreement with that of [32] who reported enhancement of pod number of pea in response to applying of rice husk biochar, while wood biochar has its less effect than all other biochar applications.

3.7. Seed Number per Pod. Seed number per pod at physiological maturity was significantly affected by different rate of biochar $(P<0.005)$. The higher number of seeds was recorded under Lantana biochar at the rate of $6 \mathrm{tha}^{-1}$ as compared to other treatments (Table 5). This implies that as the number of productive seeds per pod increases the yield per hectare also increases. The increase may be associated with increase in the number of seeds per plant, sustained nutrient supply, increased photosynthetic activity [38], and good translocation efficiency [39]. Similar to the present study, high seed numbers per pod were reported for soybean sown in low $\mathrm{pH}$ soil that was amended with biochar [32]. 
TABLE 5: Effect of different biochar on shoot fresh weight, shoot dry biomass, pod number, seed per pod, and grain yield of pea as influenced by different rate of biochar at Bule.

\begin{tabular}{|c|c|c|c|c|c|}
\hline Treatments & $\begin{array}{c}\text { SFW } \\
\text { (kg/ha) }\end{array}$ & $\begin{array}{c}\text { SDB } \\
(\mathrm{kg} / \mathrm{ha})\end{array}$ & $\begin{array}{c}\mathrm{PN} \\
(\mathrm{kg} / \mathrm{ha})\end{array}$ & $\begin{array}{c}\mathrm{SP} \\
(\mathrm{kg} / \mathrm{ha})\end{array}$ & $\begin{array}{c}\mathrm{GY} \\
(\mathrm{kg} / \mathrm{ha})\end{array}$ \\
\hline \multicolumn{6}{|c|}{ Different rate of biochar $(\mathrm{kg} / \mathrm{ha})$} \\
\hline Control corn & $78.50^{\mathrm{d}}$ & $10.53^{c}$ & $8.39^{\mathrm{d}}$ & $4.43^{\mathrm{c}}$ & $134.17^{\mathrm{c}}$ \\
\hline corn biochar $6 \mathrm{tha}^{-1}$ & $78.14^{\mathrm{d}}$ & $7.35^{\mathrm{c}}$ & $10.54^{\mathrm{cd}}$ & $4.17^{\mathrm{c}}$ & $134.17^{\mathrm{c}}$ \\
\hline corn biochar $12 \mathrm{tha}^{-1}$ & $108.67^{\mathrm{cd}}$ & $28.83^{\mathrm{b}}$ & $13.96^{\mathrm{c}}$ & $4.93^{\mathrm{bc}}$ & $327.67^{b}$ \\
\hline corn biochar 18 tha $^{-1}$ & $130.50^{\mathrm{bc}}$ & $28.86^{\mathrm{b}}$ & $14.90^{\mathrm{c}}$ & $5.20^{\mathrm{bc}}$ & $291.67^{b}$ \\
\hline Control Lantana & $106.47^{\mathrm{cd}}$ & $25.66^{\mathrm{b}}$ & $15.66^{\mathrm{c}}$ & $5.97^{\mathrm{ab}}$ & $383.33^{\mathrm{b}}$ \\
\hline Lantana biochar $6 \mathrm{tha}^{-1}$ & $208.53^{\mathrm{a}}$ & $42.68^{\mathrm{a}}$ & $21.67^{\mathrm{b}}$ & $7.16^{\mathrm{a}}$ & $366.50^{\mathrm{b}}$ \\
\hline Lantana biochar $12 \mathrm{t} \mathrm{ha}^{-1}$ & $163.50^{\mathrm{b}}$ & $29.57^{\mathrm{b}}$ & $28.67^{\mathrm{a}}$ & $4.45^{\mathrm{c}}$ & $504.17^{\mathrm{a}}$ \\
\hline Lantana biochar $18 \mathrm{tha}^{-1}$ & $174.83^{\mathrm{ab}}$ & $45.25^{\mathrm{a}}$ & $25.33^{\mathrm{ab}}$ & $6.12^{\mathrm{ab}}$ & $528.33^{\mathrm{a}}$ \\
\hline LSD $(P<0.05)$ & 44.40 & 8.17 & 5.52 & 1.50 & 99.63 \\
\hline $\mathrm{CV}(\%)$ & 19.33 & 17.07 & 18.12 & 16.14 & 17.05 \\
\hline
\end{tabular}

SFW = shoot fresh weight, $\mathrm{SDB}=$ shoot dry biomass, $\mathrm{PN}=$ pod number per plant, $\mathrm{SP}=$ seed number per pod, and GY = grain yield. Means with same letters are not significantly different from each other at $5 \%$ probability level.

According to [36] number of seeds/pods of pea was highly significantly affected by application of biochar of different origin.

3.8. Shoot Biomass. Shoot fresh and dry biomass yield was enhanced by application of Lantana biochar $6 \mathrm{tha}^{-1}$ and Lantana biochar $18 \mathrm{tha}^{-1}$, respectively (Table 5). One of the reasons for shoot biomass yield increase in this study was the production of more vigor growth in the higher rates of Lantana biochar. Similar to the current study, [12] reported that the highest shoot biomass yield was obtained under plants supplied with high rate of biochar.

3.9. Gain Yield. Grain yield was significantly affected by different rate of biochar $(P<0.05)$. Application of Lantana biochar at increased rates from $12-18 \mathrm{tha}^{-1}$ significantly increased grain yield compared to the rest of the treatments (Table 4). Significantly lower $(134.17 \mathrm{~kg} / \mathrm{ha})$ grain yield was recorded under unfertilized corn control and corn biochar at the rate of 6 ton/ha. Application of Lantana biochar significantly increased grain yield over the corn biochar and control treatments (Table 5). This could be attributed to reclaim in the level of soil acidity from application of biochar and in turn increases the number of pods and seeds per plant and hence grain yield.

Similarly, [30,40] noted significant increase in grain yield of teff with increasing rates of biochar. [41] also reported that application of biochar on maize grain yield had significant effect in subsequent years and maize yield increased with increasing biochar rate.

\section{Conclusion}

This study indicates that different physical properties of the soil such as bulk density, total porosity, and the chemical properties such as total nitrogen, available phosphorus, potassium, and $\mathrm{pH}$ and soil organic carbon of the soil were improved due to application of biochar compared to the control. The increased soil $\mathrm{pH}$ and soil porosity and decreasing bulk density and exchangeable acidity value may be due to the ash content in biochar. Similarly increasing soil $\mathrm{pH}$ and a reduction of exchangeable acidity were observed from the experiment. Due to the application of biochar germination percentage, mean germination time, and germination index, plant height, fresh and dry weight of shoot and roots, number of pods/plants, number of seeds/pods, and yield of it were significantly increased. Of the two feedstocks, Lantana biochar was found to have greatest effect in pea seedling growth compared to corncob biochar. Among the biochar from different feedstock, Lantana camara biochar was found to be effective in increasing agronomic parameter in comparison to other corncobs biochars. Farmers in Bule mostly practice to use liming in acidic soil, which is a shortterm increase in nutrient availability with not any longterm effect on the soil health. This practice could be easily replaced by the formation and application of biochar. This could produce the long-term beneficial effect on the soil health together with the increased yield.

\section{Conflicts of Interest}

The authors declare that there are no conflicts of interest.

\section{Acknowledgments}

The authors would like to gratefully acknowledge Dilla University for financial support and Bule Wereda Agricultural Office for providing necessary information; without their contribution, this study would have been impossible.

\section{References}

[1] T. T. Brown, R. T. Koenig, D. R. Huggins, J. B. Harsh, and R. E. Rossi, "Lime effects on soil acidity, crop yield, and aluminum chemistry in direct-seeded cropping systems," Soil Science Society of America Journal, vol. 72, no. 3, pp. 634-640, 2008. 
[2] A. Wambeke, "Formation, distribution and consequences of acid soils in agricultural development," in Proceedings of Workshop on Plant Adaptation to Mineral Stress in Problem Soils, J. M. Wright and A. S. Ferrari, Eds., p. 15, Cornell university agricultural experiemental station thaca, 1976.

[3] H. R. von Uexküll and E. Mutert, "Global extent, development and economic impact of acid soils," Plant and Soil, vol. 171, no. 1, pp. 1-15, 1995.

[4] A. Mesfin, Nature and Management of Acid Soils in Ethiopia, Addis Ababa, Ethiopia, 2007.

[5] Gedeo Zone Agricultural Office, "Bule woreda soil $\mathrm{pH}$ analysis result report," 2001.

[6] K. Y. Chan, L. Van Zwieten, I. Meszaros, A. Downie, and S. Joseph, "Agronomic values of greenwaste biochar as a soil amendment," Australian Journal of Soil Research, vol. 45, no. 8, pp. 629-634, 2007.

[7] F. Ahmad and K. H. Tan, "Effect of lime and organic matter on soybean seedlings grown in aluminum-toxic soil," Soil Science Society of America Journal, vol. 50, no. 3, pp. 656-661, 1986.

[8] N. Hakim, A. Syafriman, and G. Soepardi, "Effect of lime, fertilizers and crop residues on yield and nutrient uptake of upland rice, soybean and maize in intercropping system," in Nutrient Management for Food Crop Production in Tropical Farming System, J. V. D. Heide, Ed., pp. 349-360, Institute of Soil Fertility, Harren, the Netherlands, 1989.

[9] V. A. Haby, "Soil fertility and management of acid coastal plain soils for crop production," Communications in Soil Science and Plant Analysis, vol. 33, no. 15-18, pp. 2497-2520, 2002.

[10] J. Shamshuddin and E. A. Auxtero, "Soil solution compositions and mineralogy of some active acid sulfate soils in Malaysia as affected by laboratory incubation with lime," Soil Science, vol. 152, no. 5, pp. 365-376, 1991.

[11] N. Abebe and K. Endalkachew, "Effect of Charcoal Production on Soil Properties in Southwestern Ethiopia," Middle-East Journal of Scientific Research, vol. 9, no. 6, pp. 807-813, 2011.

[12] J. Shamshuddin, S. Muhrizal, I. Fauziah, and M. H. A. Husni, "Effects of adding organic materials to an acid sulfate soil on the growth of cocoa (Theobroma cacao L.) seedlings," Science of the Total Environment, vol. 323, no. 1-3, pp. 33-45, 2004.

[13] S. Yaman, "Pyrolysis of biomass to produce fuels and chemical feedstocks," Energy Conversion and Management, vol. 45, no. 5, pp. 651-671, 2004.

[14] H. Kaderi, "The technique of organic matter application on rice plant in acid sulfate soil (Indonesian)," Bull. Tehnik Pertanian, vol. 9, pp. 34-41, 2004.

[15] Y. Srinivasarao, K. A. Gopinath, G. Venkatesh et al., Use of Biochar for Soil Health Enhancement and Greenhouse Gas Mitigation in India, 2013.

[16] J. Lehmann and S. Joseph, Biochar for Environmental Management: Science and Technology, Earthscan, London, UK, 2009.

[17] IBI (International Biochar Initiative), Recent research on biochar's potential in soils. International biochar initiative (IBI), 2012.

[18] B. Glaser, J. Lehmann, and W. Zech, Ameliorating Physical and Chemical Properties of Highly Weathered Soils in The Tropics with Charcoal: A review. Biol Fertil Soils, vol. 35, 2002.

[19] S. P. Sohi, E. LoPez-capel, E. Krull, and R. Bol, "Biochar's roles in soil and climate change: a review of research need," Csiro Land and Water Science Report, no. 5-9, 2009.

[20] J. Lehmann, M. C. Rillig, J. Thies, C. A. Masiello, W. C. Hockaday, and D. Crowley, "Biochar effects on soil biota-a review," Soil Biology and Biochemistry, vol. 43, no. 9, pp. 1812-1836, 2011.
[21] M. Yamato, Y. Okimori, I. F. Wibowo, S. Anshori, and M. Ogawa, "Effects of the application of charred bark of Acacia mangium on the yield of maize, cowpea and peanut, and soil chemical properties in South Sumatra, Indonesia," Soil Science and Plant Nutrition, vol. 52, no. 4, pp. 489-495, 2006.

[22] G. H. Gebremedhin, H. Bereket, B. Daniel, and B. Tesfaye, "Effect of Biochar on Yield and Yield Components of Wheat and Post-harvest Soil Properties in Tigray, Ethiopia," Journal of Fertilizers \& Pesticides, vol. 6, no. 2, 2015.

[23] BWAO, Bule Wereda Agricultural Office, 2007.

[24] K. Haile, F. Mulushewa, and B. Amare, "Soil Quality Variation under Enset based Conservation Tillage and Cereal based Conventional Tillage System in Southern Highlands of Ethiopia," Advances in Plants \& Agriculture Research, 2015.

[25] FAO, "Methods of analysis of arid and semi-arid regions food and agriculture organization of the united nations," Rome Italy, 2006.

[26] G. R. Blake and H. Hartge, "Bulk Density," in Methods of Soil Analysis: Part 1-Physical and Mineralogical Methods, A. Klute, Ed., vol. 101 of Agronomy Monograph. American Society of Agronomy-Soil Science Society of America, 1986.

[27] J. M. Bremner and C. S. Mulvaney, "Nitrogen-total," in Methods of Soil Analysis. Part 2: Chemical and Microbiological Properties, A. L. Page, R. H. Miller, and D. R. Keeney, Eds., vol. 9 of Agronomy Monograph, pp. 595-624, American Society of Agronomy, Madison, Wis, USA, 2nd edition, 1982.

[28] M. Schnitzer, “Total carbon, organic matter and carbon," in Methods of Soil Analysis. Part 2, P. A. Kamara, A. Kamara, M. M. Mansaray, and P. A. Sawyerr, Eds., vol. 9, pp. 539-577, American Society of Agronomy, 2nd edition, 1982.

[29] S. Sahilemedhin and B. Taye, "Procedures for soil and plant analysis," Tech. Rep., National Soil Research Center Ethiopian Agricultural Research Organization, Addis Ababa, Ethiopia, 2000.

[30] L. Wang, C. R. Butterly, X. L. Yang, Y. Wang, H. M. S. K. Herath, and X. Jiang, "Use of crop residues with alkaline slag to ameliorate soil acidity in an Ultisol," Soil Use and Management, vol. 28, no. 2, pp. 148-156, 2012.

[31] D. L. Spark, A. L. Page, P. A. Helmke et al., Methods of Soil Analysis. Part 3-Chemical Methods, Soil Science Society of America, Inc., Madison, Wis, USA, 1996.

[32] K. Agboola and S. A. Moses, Effect of Biochar and Cowdung on Nodulation, Growth and Yield of Soybean(Glycine max L. Merrill), Department of Soil and Environmental Management, Kogi State University, Anyigba, Kogi State, Nigeria, 2015.

[33] H. F. Murphy, "A report on the fertility status and other data on some soils of ethiopia," Experiment Station Bulletin, no. 44, p. 151, College of Agriculture, Haile Sellassie I University, Dire Dawa, Ethiopia, 1968.

[34] M. Tejada and J. L. Gonzalez, "Influence of organic amendments on soil structure and soil loss under simulated rain," Soil and Tillage Research, vol. 93, no. 1, pp. 197-205, 2007.

[35] J. Lehmanna and M. C. Rilligb, Biochar for soil amendment: earth scan, London and Sterling, VA.

[36] B. Bishwoyog, N. Jasmine, P. Surya et al., Effect of Biochar from Different Origin on Physio-Chemical Properties of Soil and Yield of Garden Pea (Pisum sativum L.) at Paklihawa, Rupandehi, Nepal, Paklihawa Campus, Institute of agriculture and animal Sciences, Tribhuvan University, Rupandehi District, Lumbini Zone, Nepal, 2015. 
[37] K. Alie, K. Abibatu, M. Mary, P. Mansaray, and A. Sawyerr, "Effects of biochar derived from maize stover and rice straw on the germination of their seeds," American Journal of Agriculture and Forestry, vol. 2, no. 6, pp. 246-249, 2014.

[38] S. P. Pakhale, S. M. Navlakhe, and P. S. Solunke, "Influence of in-situ organic recycling of different legumes on soil moisture content, nutrient uptake and yield of rain fed cotton," Annual Review of Plant Physiology, vol. 23, pp. 62-65, 2009.

[39] M. D. Tandaie, B. L. Lad, S. Ubale, S. M. Dhadage, and N. V. Wandhekar, "Effect of morphological characters on seed yield of soybean," Annual Review of Plant Physiology, vol. 23, pp. 3436, 2009.

[40] A. Abewa, B. Yitaferu, Y. Selassie, and T. Amare, "The role of biochar on acid soil reclamation and yield of Teff (eragrostis tef [Zucc] trotter) in northwestern Ethiopia," Journal of Agricultural Science, vol. 6, pp. 2-9, 2014.

[41] J. Major, M. Rondon, D. Molina, S. J. Riha, and J. Lehmann, "Maize yield and nutrition during 4 years after biochar application to a Colombian savanna oxisol," Plant and Soil, vol. 333, no. 1, pp. 117-128, 2010. 


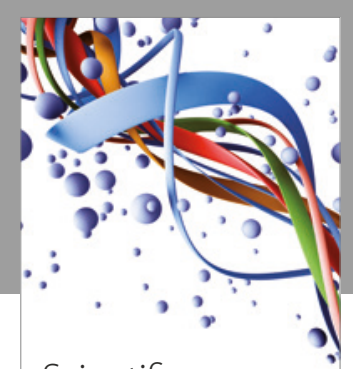

Scientifica
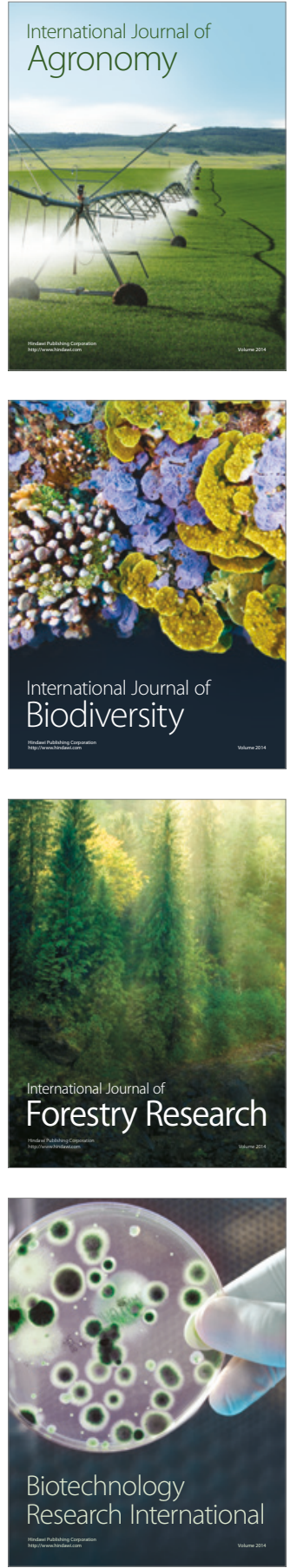
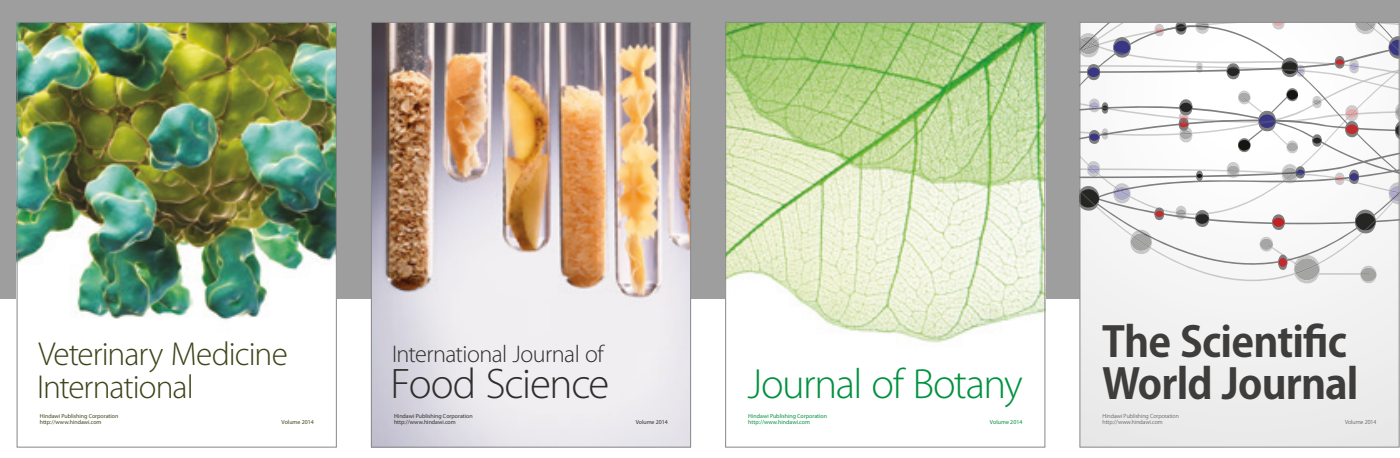

The Scientific

\section{World Journal}

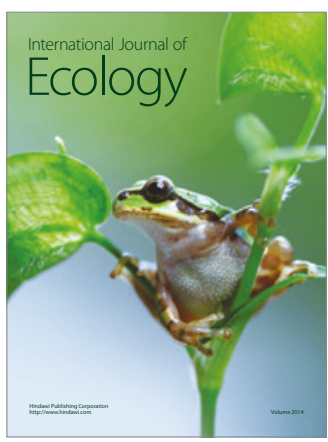

\section{Hindawi}

Submit your manuscripts at

https://www.hindawi.com
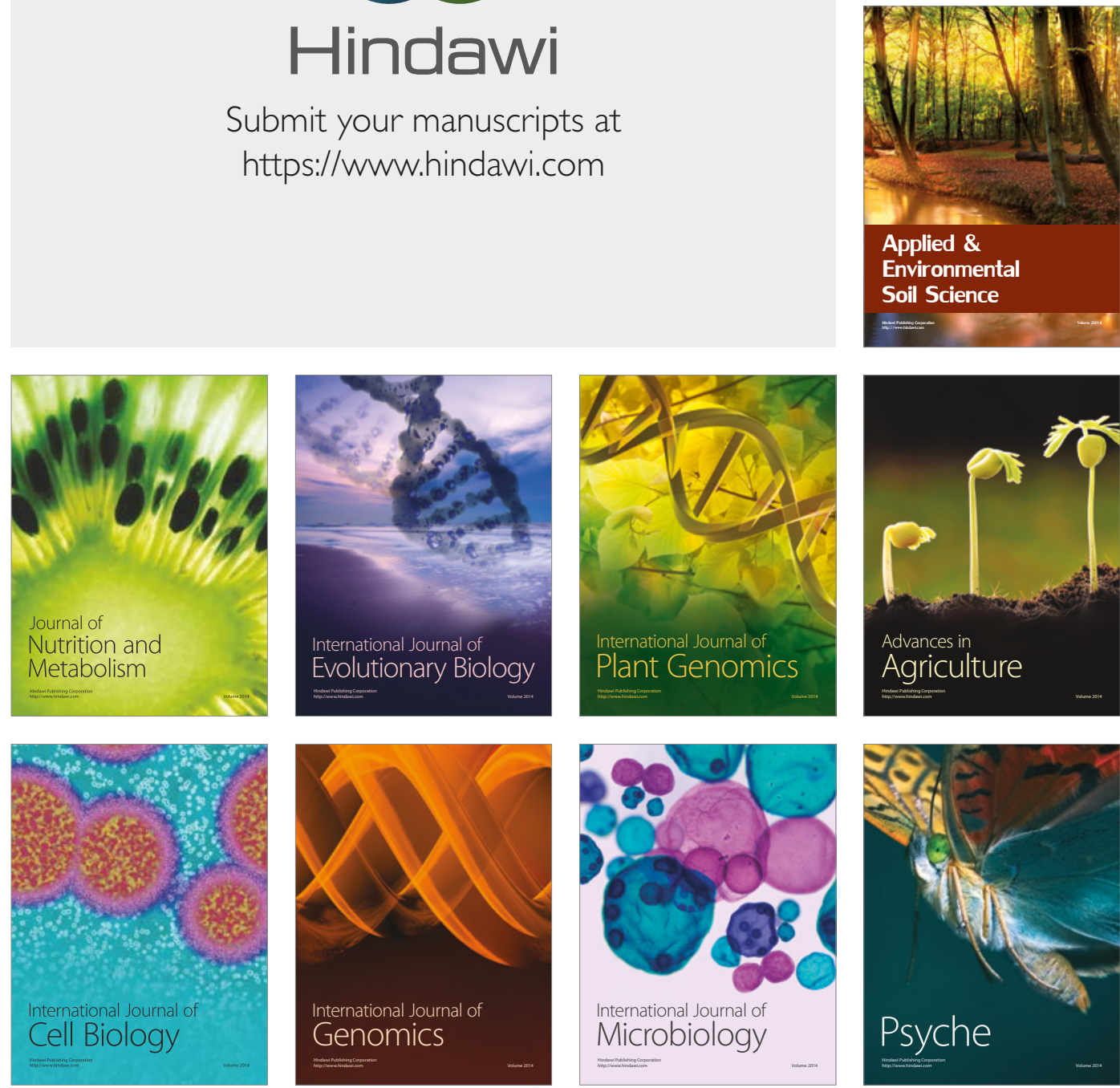

hternational Journal of Microbiology
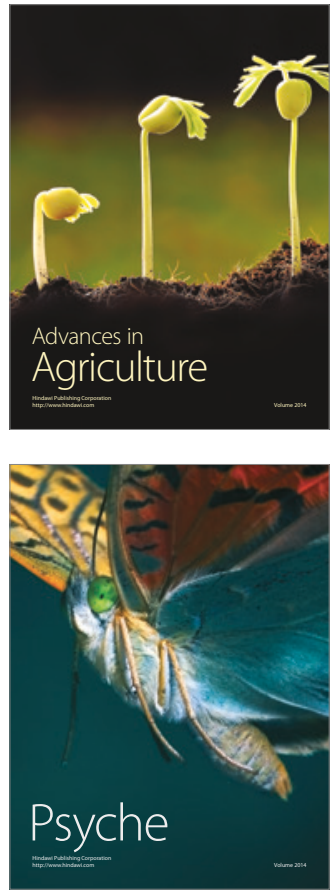